\title{
EDITORIAL
}

\section{Renewal for CMAJ}

\author{
Diane Kelsall MD MEd, Ken Flegel MDCM MSc, Kirsten Patrick MB BCh, Erin Russell MSc, Barbara Sibbald BJ, \\ Matthew B. Stanbrook MD PhD
}

Cite as: CMAJ 2017 January 9;189:E1. doi: 10.1503/cmaj.161478

I n March of last year, CMAJ's editors and many of its stakeholders feared for the journal's future. The editor-in-chief had been fired, the Journal Oversight Committee disbanded and a task force struck by the Canadian Medical Association (CMA) and Joule (the subsidiary that owns CMAJ) to re-examine CMAJ's mission. ${ }^{1}$ Some commenters questioned the 105 -year-old journal's editorial independence and even its viability.

What has happened instead is remarkable.

Far from declining, CMAJ and its offshoot CMAJ Open continued to grow and develop. We added Instagram and CMAJ News (cmajnews.com) sites to the many channels through which CMAJ is distributed. Submissions continued to flood in, and articles published in both journals were regularly highlighted on social media and in news media around the world. CMAJ Open published two-thirds more in 2016 than in 2015 - and far faster.

And there is much more planned for 2017. We'll be publishing 50 online issues a year (up from 18) with monthly print issues, redesigned to reflect CMAJ's fresh and innovative offerings.

CMAJ has a new mission, vision and values that are consistent with its history - and will help us to grow in the future (www.cmaj. $\mathrm{ca} / \mathrm{site} / \mathrm{misc} /$ about.xhtml). Most important, however, we have a new robust governance structure, ratified by both Joule and CMA's Board of Directors, that we believe will not only protect CMAJ's editorial independence, but also further its well-being.

How did this happen? It's the result of a combination of good will, hard work and teamwork from all those connected with CMAJ. The editors, staff and Editorial Advisory Board (www.cmaj. ca/content/188/10/754.1.full) simply refused to let the journal weaken or die on our watch.

Two of us (DK and KP) participated as core members of the CMA task force on CMAJ. Under the leadership of Dr. Chris Simpson, the task force set an ambitious agenda: to identify a new mission statement, goals, objectives and governance structure for CMAJ (www. cmaj.ca/site/misc/task-force.xhtml). The task force hired independent consultants to conduct stakeholder and expert interviews, a survey of CMA members, a review of best practices in medical publishing and an audit of CMAJ.

The task force explored many options for CMAJ - including ending it. The task force's investigations strongly affirmed the journal as a public good and of importance to CMA members and other physicians. The new mission statement, "To champion knowledge that matters for the health of Canadians and the rest of the world," stands as testament to CMAJ's value. The vision - Best evidence.
Best practice. Best health - encapsulates our commitment to help physicians provide high-quality health care and inform public health policy, while our promise to protect editorial independence is represented in the journal's values: Service, Evidence and Integrity.

Notably, the task force recognized that recent conflicts between CMAJ's owners and editorial leadership were largely a result of misaligned expectations related to the journal's mission and financial support, and poor communication had hampered effective conflict resolution. It concluded that journal oversight needed to be shifted from acting primarily in times of conflict to a continuously supportive role.

Building on the findings of the 2006 CMAJ Governance Review Panel (www.cmaj.ca/site/pdfs/GovernanceReviewPanel.pdf), the task force proposed creating a CMAJ governance council to serve as the steward for the journal's overall well-being. The council's mandate will include ensuring that both the editorial and business objectives align with CMAJ's mission; facilitating healthy communication between the journal's editorial and publication leadership and owners; and evaluating CMAJ's performance against agreed-upon metrics. There is a clearer mechanism for dispute resolution around editorial independence and other issues. As always, the editor-in-chief may go directly to the CMA Board of Directors on issues of editorial independence but now has the option to bring these matters first to the governance council for resolution. This body will be established in 2017.

We believe that this structure sets a solid foundation for CMAJ's future - and provides a healthier system for addressing areas of disagreement. And we are confident that the journal's new mission, vision and values will guide us over the next years.

Last spring, we asked that you engage with the task force and make your views known. ${ }^{1}$ We expressed our fervent hope that you would continue to support CMAJ. And you did. In spades.

Our heartfelt gratitude goes out to you all.

\section{Reference}

1. Kelsall D, Patrick K, Stanbrook MB, et al. Upholding the integrity of your CMAJ. CMAJ 2016;188:E113-4.

Competing interests: See www.cmaj.ca/site/misc/cmaj_staff.xhtml

Affiliations: Interim Editor-in-Chief (Kelsall), Senior Editor (Flegel), Deputy Editor (Patrick, Stanbrook), Assistant Editor (Russell), News and Humanities Editor (Sibbald), CMAJ

Correspondence to: CMAJ editor, pubs@cmaj.ca 